\title{
Coffee Leaf Scorch Bacterium: Axenic Culture, Pathogenicity, and Comparison with Xylella fastidiosa of Citrus
}

J. E. O. de Lima, Agrocitros Citrolima Ltda., Casa Branca, SP 13700, Brazil; V. S. Miranda, Fundecitrus, Araraquara, SP 14801-970, Brazil; J. S. Hartung, ARS-USDA, Beltsville, MD 20705-2350; R. H. Brlansky, CREC, University of Florida, Lake Alfred, 33850; and A. Coutinho, S. R. Roberto, and E. F. Carlos, Fundecitrus, Brazil

\begin{abstract}
de Lima, J. E. O., Miranda, V. S., Hartung, J. S., Brlansky, R. H., Coutinho, A., Roberto, S. R., and Carlos, E. F. 1998. Coffee leaf scorch bacterium: Axenic culture, pathogenicity, and comparison with Xylella fastidiosa of citrus. Plant Dis. 82:94-97.

Symptoms of coffee leaf scorch (CLS) appear on young flushes of field plants as large marginal and apical scorched areas on recently mature leaves. Affected leaves drop, shoot growth is stunted, and apical leaves are small and chlorotic. Symptoms may progress to shoot dieback. Only scorched leaves which could not be related to other known agents consistently contained bacteria and bacterial agglomerates when observed with light microscopy. Only plants with these symptoms were positive in enzyme-linked immunosorbent assay (ELISA) tests using antiserum to Xylella fastidiosa Wells et al. The bacterium Xylella fastidiosa Wells et al. was isolated in November 1995 from coffee (Coffea arabica) leaves with scorch symptoms on supplemented periwinkle wilt medium. Colonies were circular, dome-shaped, white, and 0.5 to 1.5 $\mathrm{mm}$ in diameter. Two of 10 young coffee seedlings stem-inoculated with a suspension of the isolated X. fastidiosa in January 1996 showed leaf scorch symptoms 3 to 5 months later, contained bacteria in xylem extracts, and reacted positively in ELISA using antiserum to the citrus variegated chlorosis (CVC) strain of $X$. fastidiosa. ELISA-positive bacteria were reisolated from this plant. None of the symptomless plants, including controls, revealed bacteria on microscopic examinations, ELISA, or isolation attempts. Antisera developed against cultured bacteria from both CLS and CVC plants reacted positively against plant extracts of both diseases in dot im-

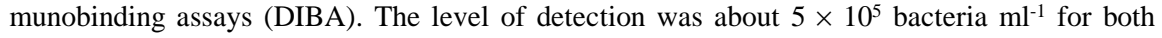
homologous and heterologous reactions. The polymerase chain reaction amplification products produced by CLS and CVC strains of X. fastidiosa were indistinguishable. Geographical distribution of these strains is not the same. CLS is widespread and usually occurs if coffee is adjacent to CVC-affected citrus. However, CVC does not always occur when citrus is grown adjacent to CLS-affected coffee. The bacteria are closely related, if not identical.
\end{abstract}

Additional keywords: amarelinho, Citrus sinensis, diagnosis, orange, PCR, requeima do café

Leaf scorching on coffee (Coffea arabica L.) plants was found in São Paulo, Brazil in 1995. Of the two principal coffee varieties grown in São Paulo, "Mundo Novo" and "Catuai Amarelo," the most severe symptoms were found in the latter. Symptoms begin with apical and marginal leaf scorch (Fig. 1), reduction in internode length of new flush, small, pale green to yellow leaves, shoot dieback, and overall plant stunting. Fruit size and yield are generally reduced. Symptoms are more evident during the winter, especially during periods of water stress. In the spring, with rain, affected leaves drop and plant appearance improves as new shoots are produced.

Corresponding author: R. H. Brlansky E-mail: rhby@icon.lal.ufl.edu

Florida Agricultural Experiment Station Journal Series No. R-05780.

Accepted for publication 6 October 1997.

Publication no. D-1997-1117-02R

(C) 1998 The American Phytopathological Society
Actual plant death due to the disease may take several years to occur.

Serological and polymerase chain reaction (PCR) tests indicated the presence of the bacterium Xylella fastidiosa Wells et al. in symptomatic coffee plants (20). Xylem extracts from affected leaves contained bacteria morphologically similar to $X$. fastidiosa, which reacted positively to antiserum prepared against an isolate of $X$. fastidiosa from citrus affected with citrus variegated chlorosis (CVC) (16). The bacteria were isolated in supplemented periwinkle wilt (SPW) culture medium (10), and the disease was named "requeima do café" or coffee leaf scorch (CLS). Similar isolations were later confirmed elsewhere (2). The economic significance of CLS is unknown. Extensive coffee plantations have been eliminated in São Paulo. CLS was not reported prior to 1995 , possibly because leaf scorching was often attributed to other problems, including the coffee leaf miner (Perileucoptera coffeella Guein. \& Meneville), coffee rust (Hemileia vastatrix Berk \& Br.), water stress, or destruction of the root system by nematodes. It is now suspected that CLS may have been the problem, since many remaining coffee plants have tested positive for Xylella.

The objectives in this study were to isolate the CLS bacterium in vitro, to produce polyclonal antiserum against it, and to confirm its pathogenicity by fulfilling Koch's postulates. In addition, the distribution of the bacteria in infected plants and the serological relationship between the coffee and citrus bacterial strains were studied. The close serological relationship between the coffee and citrus strains of $X$. fastidiosa was confirmed by PCR assay.

\section{MATERIALS AND METHODS}

$X$. fastidiosa diagnosis. Bacterial detection was carried out using light microscopy (LM), scanning electron microscopy (SEM), dot immunobinding assays (DIBA), and enzyme-linked immunosorbent assays (ELISA). We obtained xylem extracts for LM by the syringe method $(15,17)$. Briefly, leaf petioles were excised and fitted to a $2-$ to $4-\mathrm{cm}$ long by $0.2-\mathrm{cm}$ diameter plastic tube attached to a syringe. Sterilized, distilled water was then pushed through the xylem by applying manual pressure to the syringe to release bacteria from the vessels. The resulting drops of extract were dried on glass slides, stained with methylene blue, and observed at $400 \times$ with a light microscope for the presence of bacilliform cells or their agglomerates typical of $X$. fastidiosa $(6,11,24)$.

Immunofluorescence assay was carried out on syringe extracts as prepared above, or by using membrane entrapment of extracts (3). Four to five petioles were chopped in approximately $2 \mathrm{ml}$ of $0.02 \mathrm{M}$ Tris ( $\mathrm{pH}$ 8.2) buffer and the supernatant was passed through a Nucleopore $25-\mathrm{mm}$ Swin-Lok filter assembly (Nucleopore Corporation, Pleasanton, CA 94566) containing a $5.0-\mu \mathrm{m}$ polycarbonate membrane for trapping cellular debris and a $0.2 \mu \mathrm{m}$ membrane for trapping bacteria. The latter was then removed and incubated for $1 \mathrm{~h}$ in a 1:20 dilution of $X$. fastidiosa-specific immunoglobulin ( $\mathrm{IgG}$ ) prepared to the citrus variegated chlorosis (CVC) strain (ca. $1 \mathrm{mg} \mathrm{ml}^{-1}$ ) in Tris-BSA-gelatin buffer (20 mM Tris, $0.9 \% \mathrm{NaCl}$, pH 8.2 containing $0.1 \%$ bovine serum albumin and $1 \%$ gelatin). After a wash in Tris-BSA-gelatin buffer, the membranes were incubated in tetramethyl-rhodamine isothiocyanate (TRITC)-labeled goat anti-rabbit IgG (1:20) 
for $1 \mathrm{~h}$. After washing, the membranes were mounted and viewed with an epifluorescence microscope using a 580 to $590 \mathrm{~nm}$ wavelength filter as previously described (3).

SEM observations were carried out by fixing root and stem xylem or whole petioles in Karnovsky solution for 48 h, postfixing in $1 \%$ osmium tetroxide for $4 \mathrm{~h}$, dehydrating in an acetone series, transferring to $100 \%$ ethanol, and drying on a Ladd critical point dryer using $\mathrm{CO}_{2}$ as carrier fluid. The samples were then sectioned with a razor blade through the xylem, coated with gold/palladium using a Ladd sputter-coater, and viewed in a Hitachi S530 scanning electron microscope.

Extracts for both the previously described DIBA (13) and double-antibody sandwich (DAS)-ELISA $(9,19,32)$ tests were prepared by cutting approximately 40 $\mathrm{mg}$ of excised tissue (root or stem xylem, or whole petioles) into pieces approximately $1 \mathrm{~mm}$ long. These were put into $400 \mu \mathrm{l}$ of distilled, sterilized water and centrifuged at $500 \times g$ for 2 min to help release bacteria into the supernatant.

Field symptoms and bacterial distribution. In order to relate leaf symptoms to the presence of $X$. fastidiosa in coffee, leaves showing symptoms both from unknown or known (coffee rust and coffee leaf miner) causes, as well as normal-appearing coffee leaves, both from symptomless branches in the field or healthy controls under screen, were analyzed by LM for the presence of bacteria. Sixteen to 30 leaves of each type were examined from two coffee blocks in Casa Branca, São Paulo. X. fastidiosa identification was confirmed on several samples by immunofluorescence. Bacteria were observed in both orange and coffee roots (2- to 5-mm diameter), stems (3- to 8-mm diameter), and leaf petioles examined by SEM. The bacteria were identified as $X$. fastidiosa by LM and ELISA tests. Greenhouse-grown 4- to 12-month-old coffee plants (from seed) were used as healthy controls. Scorched coffee leaves and orange leaves with CLS and CVC symptoms and bacteria in the petioles (LM) were used as positive controls.

Isolation, culture, and antibody production. Xylem extracts were obtained by surface-disinfesting petioles or veins from symptomatic leaves of coffee with CLS for $1 \mathrm{~min}$ in $70 \%$ ethanol and $3 \mathrm{~min}$ in $10 \%$ bleach, washing for $5 \mathrm{~min}$ in sterile distilled water, cutting approximately 1-mm pieces into 1 to $2 \mathrm{ml}$ of SPW (10) broth, and centrifuging at $700 \times g$ for 2 to $3 \mathrm{~min}$ to help release bacteria from the xylem. Supernatant aliquots of $1 \mathrm{ml}$ were then inoculated in liquid or on solid SPW media and incubated microaerobically in the dark at $27^{\circ} \mathrm{C}$. After bacterial colonies had grown and were confirmed to be $X$. fastidiosa by colony morphology and PCR, washed cells from pure cultures in phosphate buffered saline with $0.001 \%$ sodium azide were sent to Cocalico Biologicals, Inc. (Reamstown, PA) for antisera production in rabbits. The $\mathrm{IgG}$ fraction of the serum was isolated by protein A column chromatography (18), adjusted to approximately $1 \mathrm{mg} \mathrm{ml}^{-1}$, and an aliquot conjugated with alkaline phosphatase, using glutaraldehyde. Reactivity was then tested using immunofluorescence as described above, DIBA at a doubling dilution series from 1:10,000 to $1: 160,000$, and ELISA at 1:2,000. Test bacteria were from culture and were tested in a 10 -fold dilution series from $\sim 10$ to $\sim 10^{8}$ bacteria $\mathrm{ml}^{-1}$.

Pathogenicity. Bacteria were isolated on SPW medium from scorched coffee leaves collected at Casa Branca, São Paulo, as described above, and subcultured once in the same medium. A log-phase cell suspension was obtained by growing 10 to 14 days in SPW media and was collected by centrifugation at $3,500 \times g$ for $5 \mathrm{~min}$, followed by resuspension of the pellet with sterilized distilled water to a concentration of $\sim 10^{9}$ cells per ml. A flap of stem tissue was raised on the stem of 2-month-old coffee plants, cv. Mundo Novo, by cutting tangentially upward with a razor blade, exposing the wood. Drops of bacterial suspension were then continuously applied underneath the flap with a pipette until 100 $\mu \mathrm{l}$ or $\sim 10^{8}$ cells per plant had been taken up in approximately $2 \mathrm{~h}$. Ten plants were inoculated on 11 January 1996, and the same number of control plants were mock-inoculated with water or not inoculated. A few drops of methylene blue were added to the water in one control plant to indicate translocation, showing uptake to all plant extremities above the inoculation point. Detection of bacteria by LM and ELISA and reisolation attempts were carried out 80 and 105 days after inoculation.

Bacterial size, serology, and PCR assay. One hundred bacterial cells from three coffee petiole samples were measured using a light microscope with a reticulated ocular calibrated to a template slide.

Purified rabbit $\mathrm{IgG}$ prepared against cultured $X$. fastidiosa from CLS was compared with purified rabbit $\mathrm{IgG}$ prepared against cultured $X$. fastidiosa from CVC in homologous and heterologous immunofluorescence and DIBA tests. The dilution end-point was determined for the dot assay by counting bacteria in $1 \mu$ l-aliquots and preparing fivefold dilution series starting at $\sim 5 \times 10^{7}$ bacteria $\mathrm{ml}^{-1}$.

$X$. fastidiosa strains 96-1, isolated from CLS-diseased coffee, and 10T, isolated from CVC-diseased citrus, were grown to stationary phase in SPW broth. Cells were washed twice and resuspended in water. Cells were added to PCR master mix in a 10-fold dilution series starting at $\sim 5 \times 10^{6}$ cells. Amplification conditions were as previously described (22) using the primer pair 272-2 and CVC-1. Electrophoresis of amplification product was at $100 \mathrm{~V}$ through $2 \%$ NuSieve (FMC, Rockland, ME) agarose gels.

\section{RESULTS AND DISCUSSION}

X. fastidiosa diagnosis. X. fastidiosa was easily observed by SEM in CLS-affected coffee and CVC-affected citrus rootlets and small branches. This bacterial presence was confirmed by LM and DASELISA. Similar bacterial distribution was found in citrus in a previous study (15). $X$. fastidiosa also has been observed in both branches and roots in other plants, including peach $(1,31)$. Therefore, $X$. fastidiosa can be distributed throughout an entire plant, and must be moved downward to the root system, since the sharpshooter leafhopper vectors are known to feed exclusively on aerial plant parts (23). When viewed by SEM, bacteria were observed colonizing the lumen of the xylem vessels (Fig. 2), frequently resulting in plugs composed of bacteria imbedded in a matrix apparently of plant origin, as described for Pierce's disease of grapes $(8,11,12,24)$. Based on SEM observations, the bacteria in roots, stems, and petioles of coffee and citrus were indistinguishable, and had characteristics similar to those previously described in citrus $(5,11,26)$ as well as in other plants $(4,14,24,28,29)$.

Field symptoms and bacterial distribution. Twenty-nine of 30 coffee leaves with scorch symptoms had many bacteria in xylem extracts, observed with the LM as scattered cells or typical bacterial agglomerates. None of the leaves from control plants grown from seed under screen con-

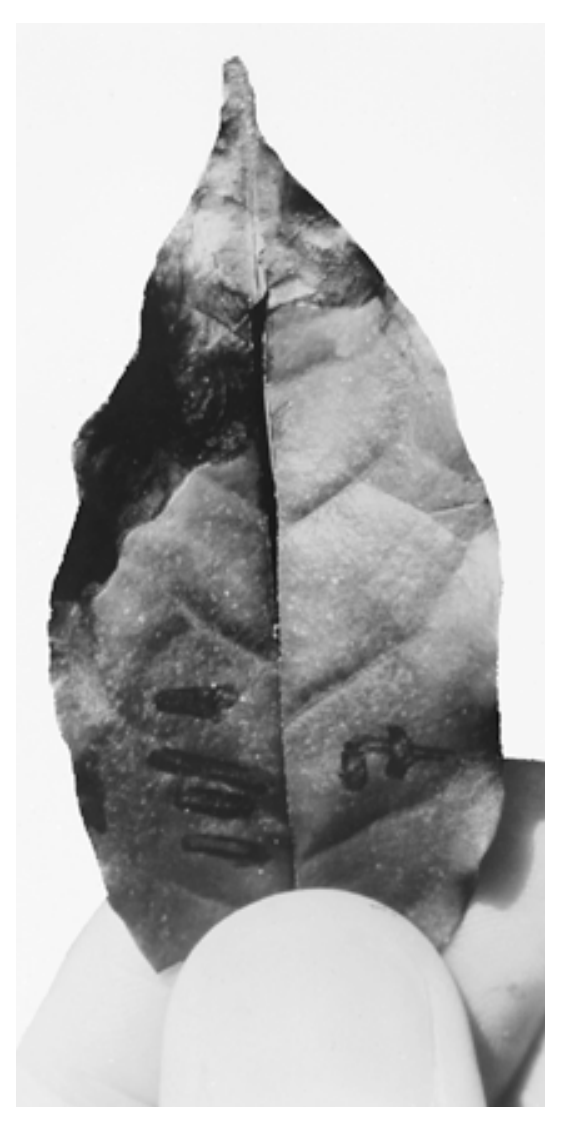

Fig. 1. Symptoms of coffee leaf scorch on coffee (Coffea arabica L. cv. "Mundo Novo"). 
tained bacteria. Presumptive $X$. fastidiosa, however, is widespread in plants exposed in the field, since $10 \%$ of symptomless leaves also had bacteria. These bacterial populations in asymptomatic plants may indicate recent infections. Alternatively, they may represent field infection by strains of $X$. fastidiosa not related to CLS. Some leaves with scorch-like symptoms that could be partially attributed to coffee leaf miner or coffee rust also had bacteria (25 and 14\% of leaves sampled, respec- tively). Symptoms of CLS could be masked in those leaves by the other disease or pest symptoms. Plants with scorched leaves showing bacteria in the xylem also had a wide range of decline symptoms. Some had nearly healthy appearance with just a few symptomatic leaves. More commonly, as the number of scorched leaves increased, defoliation and reduction in plant and leaf size were noticeable. In extreme cases, most branches had retained only the most distal leaves. These were

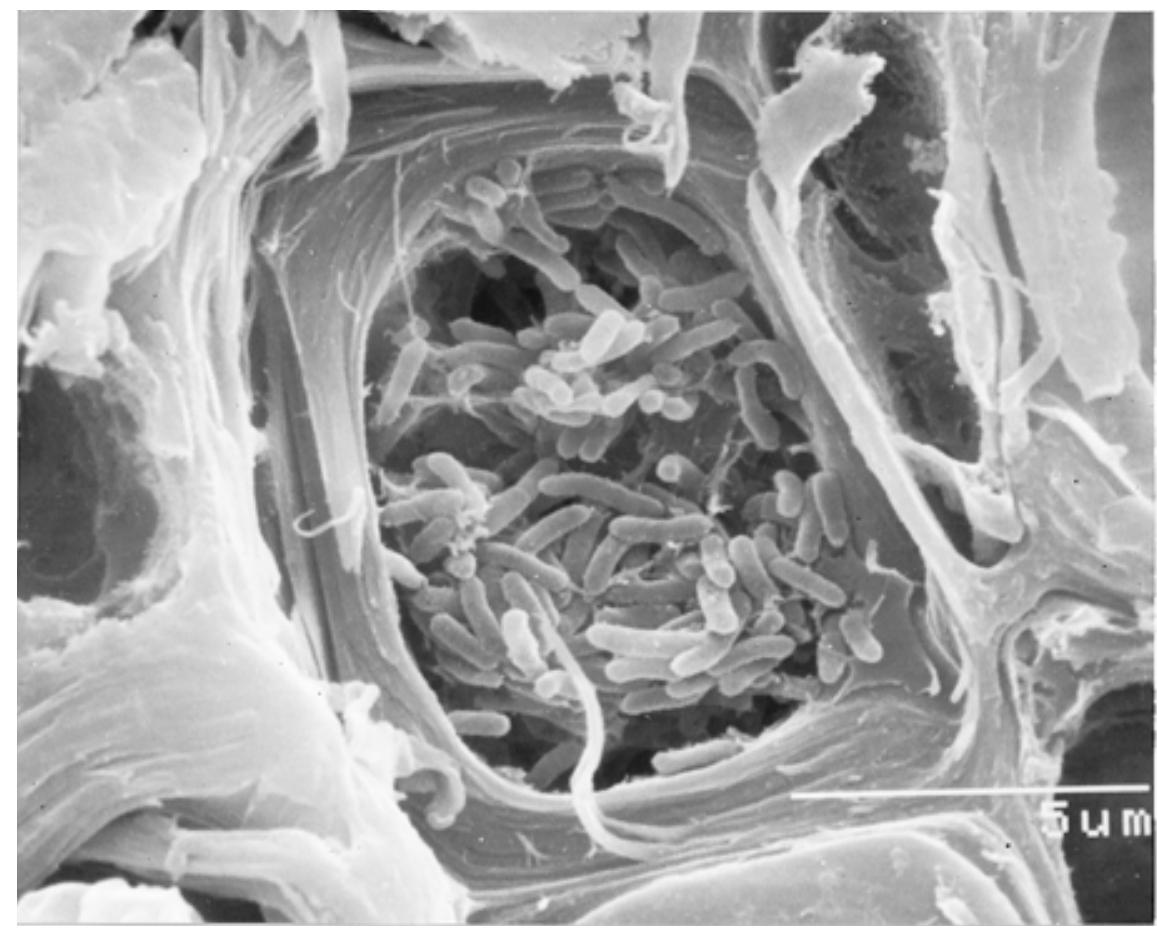

Fig. 2. Xylella fastidiosa bacteria in a cross-section of petiole xylem vessel affected by coffee leaf scorch as seen by scanning electron microscopy.

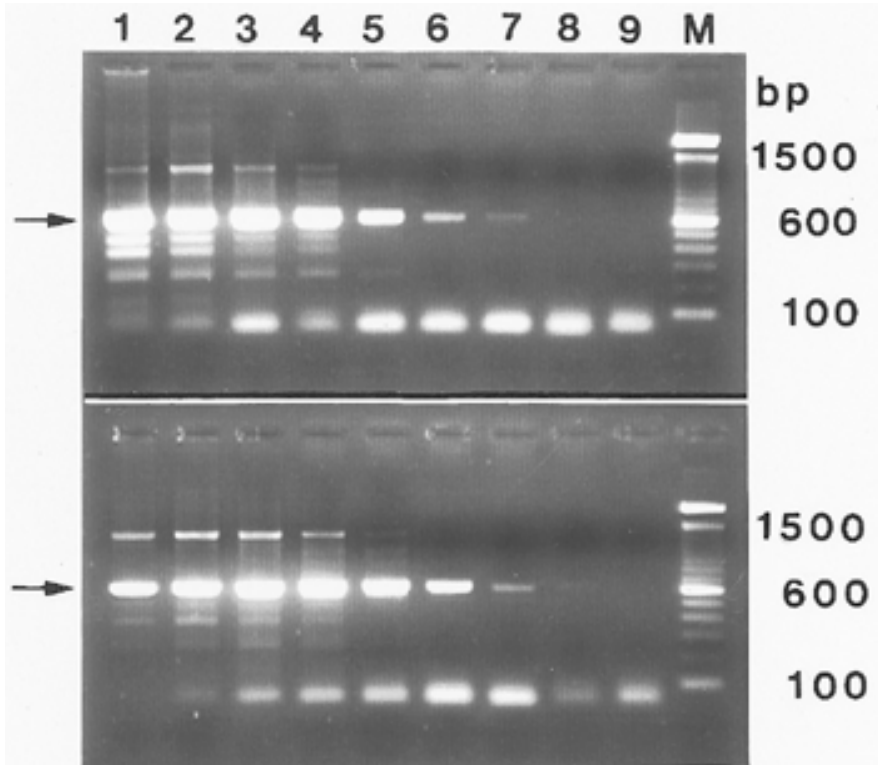

Fig. 3. Polymerase chain reaction (PCR)-amplification products produced by Xylella fastidiosa isolated from coffee leaf scorch-diseased coffee (top) and from citrus variegated chlorosis-diseased citrus (bottom). Bacteria were added to PCR in 10-fold dilution series beginning with $\sim 5 \times 10^{6}$ cells per reaction in lane 1 . Lane 9 contained the deionized water-only negative control, and lane " $\mathrm{M}$ " contained a 100-bp ladder as a size standard.

typically small, chlorotic, and scorched, and the plants were severely stunted. These plants contained many bacteria and bacterial agglomerates in xylem extracts from roots, stems, and leaves, easily observed by LM.

Isolation, culture, and antibody production. Isolation was successfully completed from 6 of 6 petioles of coffee leaves with CLS symptoms. Slow-growing bacterial colonies were observed approximately 20 days after inoculation. The colonies were circular, dome-shaped, white, and were 0.5 to $1.5 \mathrm{~mm}$ in diameter after 30 days. Morphological characteristics of the bacteria were similar to those of CVC $X$. fastidiosa (17), and other $X$. fastidiosa (29). Isolated bacteria repeatedly reacted positively in ELISA tests using antiserum to $X$. fastidiosa. Purified IgG from the polyclonal antiserum reacted positively to xylem extracts of CLS-affected plants in immunofluorescence tests at 1:20 dilution. The same extracts, as well as $X$. fastidiosa isolated from them, reacted positively in ELISA at 1:2,000, and in DIBA at all dilutions tested, from $1: 10,000$ to $1: 160,000$. Dilution endpoint was determined for the ELISA at $\sim 10^{5}$ bacteria $\mathrm{ml}^{-1}$.

Pathogenicity. Two of 10 coffee plants inoculated with a suspension of $X$. fastidiosa from CLS-infected coffee leaves developed scorched leaf symptoms after 3 months. Bacteria with the characteristic morphology of $X$. fastidiosa were observed by LM in xylem extracts from a scorched leaf from these plants. The average ELISA reading for a mid-vein extract of the plants, using an antiserum against CVC $X$. fastidiosa, was 0.347 , compared with 0.060 , 0.050 , and 0.930 for a healthy coffee plant extract, a water blank, and a positive CLSinfected coffee plant extract, respectively. $X$. fastidiosa was observed in culture 15 to 20 days after inoculating leaf vein extracts into SPW broth. LM observations of the isolated bacteria revealed morphological characteristics similar to the inoculated $X$. fastidiosa. The average ELISA results for both cultures were also positive (1.519), compared to 0.062 for a healthy coffee plant extract, 0.070 for a water blank, and 1.002 for a positive CLS plant. The successfully inoculated plants continued to have CLS symptoms and tested positive again for the pathogen in September 1996 using PCR assay (22). None of the control plants or the remaining inoculated plants without scorch symptoms had bacteria detectable with LM examination of xylem extracts, or positive ELISA readings or PCR assays. We therefore fulfilled Koch's postulates relating $X$. fastidiosa and "requeima do café" or coffee leaf scorch. The low level of successful inoculation of cultured bacteria into plants has been found for some tree strains of $X$. fastidiosa $(10,30)$. Recently field observations indicate that cv. Mundo Novo may be more tolerant to CLS symptoms than cv. Catuai Amarelo. This difference may further ac- 
count for the low level of inoculation success we obtained in pathogenicity tests.

Bacterial size, serology, and PCR assay. The rod-shaped bacteria extracted from CLS-affected petioles had dimensions of $0.4 \mu \mathrm{m} \pm 0.02 \mu \mathrm{m}$ by $2.5 \mu \mathrm{m} \pm 0.5$ $\mu \mathrm{m}$ dimensions, similar to $X$. fastidiosa from citrus (17) as well as from other plants $(11,24)$.

Purified rabbit IgG against $X$. fastidiosa cultured from both CVC- and CLS-affected plants reacted indistinguishably to both homologous and heterologous extracts in immunofluorescence and DIBA tests. The DIBA dilution endpoints were the same for all reaction and cross-reaction combinations, i. e. $\sim 5 \times 10^{5}$ bacteria $\mathrm{ml}^{-1}$.

The PCR amplification products produced by the CVC and CLS strains of $X$. fastidiosa were indistinguishable, and both strains had the same dilution endpoint in the PCR assay (Fig. 3). This is significant because this primer pair did not directly amplify any product from any $X$. fastidiosa strain from any host except citrus (22). In the previous work, all of the strains tested, except for the citrus strains, were of North American origin. The $X$. fastidiosa strains tested previously from Brazil, all from CVC-diseased trees, also were readily distinguished by random amplified polymorphic DNA (RAPD)-PCR analyses from the North American strains of $X$. fastidiosa (21). Thus, the coffee and citrus strains of $X$. fastidiosa are distinct from the North American strains.

All available data is consistent with hypothesis that the coffee and citrus strains of $X$. fastidiosa in São Paulo are closely related or identical to each other. Since the same leafhopper vectors of CVC commonly are present in coffee plantations in São Paulo, it is possible that strains from a natural endemic population in other hosts were challenge-inoculated into each crop until virulent strains were selected. It is common for $X$. fastidiosa strains to be inoculated and grow in different plants, behaving as pathogens in one or more of the host species $(7,11,24)$. Geographical distribution of the coffee and citrus strains, however, does not appear to be congruent, since CLS is easily detected adjacent to healthy-appearing orange groves and in areas where CVC has not been reported or occurs at low levels $(16,27)$. In addition, since coffee is propagated via seeds, and Xylella-related diseases are not seedtransmitted $(11,24)$, the dissemination in coffee throughout the state of São Paulo must have occurred through the leafhopper vectors and, therefore, does not seem to be recent. In contrast, $\mathrm{CVC}$ has been rapidly disseminated by contaminated budwood. The detection of CVC in orange trees was officially reported in 1987 and probably was observed a few years earlier (25). This evidence suggests that different strains of $X$. fastidiosa may be involved in the coffee and the orange diseases, or the strains may be identical. We have initiated such crossinoculation experiments to further evaluate the relation between these strains.

\section{ACKNOWLEDGMENTS}

We thank Dr. K. L. Manjunath, Cícero A. Massari, Roberto A. Salva, Renê R. Palma, Edimar R. Zavatti, Marcos R. Felippe, Diann Achor, Craig Davis, and Deborah Howd for technical assistance.

\section{LITERATURE CITED}

1. Aldrich, J. H., Gould, A. B., and Martin, F. G. 1992. Distribution of Xylella fastidiosa within roots of peach. Plant Dis. 76:885-888.

2. Beretta, M. J. G., Harakava, R., Chagas, C. M., Derrick, K. S., Barthe, G. A., Ceccardi, T. L., Lee, R. F., Paradela, O., Sugimori, M. H., and Ribeiro, I. A. 1996. First report of Xylella fastidiosa in coffee. Plant Dis. 80:821.

3. Brlansky, R. H., and Lee, R. F. 1990. Detection of Xanthomonas campestris pv. citrumelo and $X$. citri from citrus using membrane entrapment immunofluorescence. Plant Dis. 74:863-868.

4. Brlansky, R. H., Timmer, L. W., French, W. J., and McCoy, R. E. 1983. Colonization of the sharpshooter vectors, Oncometopia nigricans and Homalodisca coagulata by xylem-limited bacteria. Phytopathology 73:530-535.

5. Chang, C. J., Garnier, M., Zreik, L., Rosseti, V., and Bové, J. M. 1993. Citrus variegated chlorosis: cultivation of the causal bacterium and experimental reproduction of the disease. Pages 294-300 in: Proc. 12th Conf. IOCV, P. Moreno, J. V. da Graca and L. W. Timmer, eds. IOCV, Riverside.

6. Davis, M. J., French, W. J., and Schaad, N. W. 1981. Axenic Culture of the bacteria associated with phony peach disease of peach and plum leaf scald. Curr. Microbiol. 6:309-314

7. Freitag, J. H. 1951. Host range of the Pierce's disease virus grapes as determined by insect transmission. Phytopathology 41:920-934.

8. Fry, S. M., and Milholland, R. D. 1990. Response of resistant, tolerant, and susceptible grapevine tissues to invasion by the Pierce's Disease bacterium, Xylella fastidiosa. Phytopathology 80:66-69.

9. Garnier, M., Chang, C. J., Zreik, L., Rosseti, V., and Bové, J. M. 1993. Citrus Variegated Chlorosis: serological detection of Xylella fastidiosa, the bacterium associated with disease. Pages 301-305 in: Proc. 12th Conf. IOCV, P. Moreno, J. V. da Graca and L. W. Timmer, eds. IOCV, Riverside.

10. Hartung, J. S., Beretta, M. J. G., Brlansky, R. H., Spisso, J., and Lee, R. F. 1994. Citrus variegated chlorosis bacterium: axenic culture, pathogenicity and serological relationships with other strains of Xylella fastidiosa. Phytopathology 84:591-597.

11. Hopkins, D. L. 1989. Xylella fastidiosa: xylem-limited bacterial pathogen of plants. Annu. Rev. Phytopathol. 27:271-290.

12. Huang, Pi-Yu, Milholland, R. D., and Daykin, M. E. 1986. Structural and morphological changes associated with the Pierce's Disease bacterium in Bunch and Muscadine grape tissues. Phytopathology 76:1232-1238.

13. Lee, R. F., Beretta, M. J. G., Derrick, K. S., and Hooker, M. E. 1992. Development of a serological assay for citrus variegated chlorosis-a new disease of citrus in Brazil. Proc. Fla. State Hortic. Soc. 105:32-35.

14. Leu, L. S., and Su, C. C. 1993. Isolation, cultivation, and pathogenicity of Xylella fastidiosa, the causal bacterium of pear leaf scorch disease in Taiwan. Plant Dis. 77:642-646.

15. Lima, J. E. O. de. 1996. A pesquisa sobre Amarelinho no FUNDECITRUS. Laranja 16(2):137-144

16. Lima, J. E. O. de, Miranda, V. S., Coutinho, A., Roberto, S. R., and Carlos, E. F. 1996.
Distribuição de Xylella fastidiosa no cafeeiro, nas regiões caffeeiras, e seu isolamento in vitro. Fitopatol. Bras. 21:392-393.

17. Lima, J. E. O. de, Miranda, V. S., Coutinho, A., Roberto, S. R., Palma, R. R., and Pizzolitto, A C. 1996. Método de extração do conteúdo do xilema para diagnóstico da Clorose Variegada dos Citros. Fitopatol. Bras. In press.

18. Miller, T. J., and Stone, H. O. 1987. The rapid isolation of ribonuclease free immunoglobulin $\mathrm{G}$ by protein A-Sepharose affinity chromatography. J. Immunol. Methods 24:111-125.

19. Nomé, S. F., Raju, B. C., Goheen, A. C. Nyland, G., and Docampo, D. 1980. Enzymelinked immunosorbent assay for Pierce's disease bacteria in plant tissues. Phytopathology 70:746-749.

20. Paradela Filho, O., Sugimori, M. H., Riberio, I. A., Machado, M. A., Laranjeira, F. F., Garcia Jr., A., Beretta, M. J. G., Harakava, R., Rodrigues Neto, J., and Beriam, L. O. S. 1996. Primeira constatação em cafeeiro no Brasil da Xylella fastidiosa causadora da clorose variegada dos citros. Laranja 16(2):135-136

21. Pooler, M. R., and Hartung, J. S. 1995. Genetic relationships among strains of Xylella fastidiosa from RAPD-PCR data. Curr. Microbiol. 31:134-137.

22. Pooler, M. R., and Hartung, J. S. 1995. Specific PCR detection and identification of $X y$ lella fastidiosa strains causing citrus variegated chlorosis. Curr. Microbiol. 31:377-81.

23. Purcell, A. H. 1979. Leafhopper vectors of xylem-borne plant pathogens. Pages 603-625 in: Leafhopper Vectors and Disease Agents. K. Maramorosch and K. F. Harris, eds. Academic Press, New York.

24. Raju, B. C., and Wells, J. M. 1986. Diseases caused by fastidious xylem-limited bacteria and strategies for management. Plant Dis. 70:182-186.

25. Rosseti, V. 1993. Citrus variegated chlorosis, a new disease in Brazil, a review. Pages 449542 in: Proc. 12th Conf. IOCV, P. Moreno, J. V. da Graca and L. W. Timmer, eds. IOCV, Riverside.

26. Rosseti. V., Garnier, M., Bové, J. M., Beretta, M. J. G., Teixeira, A. R. R., Quaggio, J. A. and De Negri, J. D. 1990. Presencé de bacteries dans le xyléme d'oranges atteinst de chlorose variegée, une nouvelle maladie des agrumes au Brésil. C. R. Acad. Sci 310(3):345-349.

27. Salva, R. A., Roberto, S. R., and Carlos, E. F. 1996. Situação da clorose variegada dos citros no Estado de São Paulo. Laranja 16(2):155-164.

28. Tyson, G. E., Stojanovic, B. J., Kuklinski, R. F., DiVittorio, T. J., and Sullivan, M. L. 1985. Scanning electron microscopy of Pierce's disease bacterium in petiolar xylem of grape leaves. Phytopathology 75:264-269.

29. Wells, J. M., Raju, B. C., Huang, H., Weilburg, W. G., Mandelco-Paul, L., and Brenner, D. J. 1987. Xylella fastidiosa gen Nov., sp. Nov: gram-negative, xylem-limited, fastidious plant bacteria related to Xanthomonas spp. Int. J. Syst. Bacteriol. 37(2):136-143.

30. Wells, J. M., Raju, B. C., and Nyland, G. 1983. Isolation, culture and pathogenicity of the bacterium causing phony disease of peach. Phytopathology 73:859-862.

31. Wells, J. M., Weaver, D. J., and Raju, B. C. 1980. Distribution of Ricketsia-like bacteria in peach, and their occurrence in plum, cherry, and some perennial weeds. Phytopathology 70:817-820.

32. Younce, C. E., and Chang, C. J. 1987. Detection of xylem-limited bacteria from sharpshooter leafhoppers and their feeding hosts in peach environs monitored by culture isolations and ELISA techniques. Environ. Entomol. 16:68-71. 